\title{
Prenatal testing and pregnancy termination in Sri Lanka: views of medical students and doctors
}

\author{
B Simpson 1, VHW Dissanayake ${ }^{2}$, D Wickramasinghe ${ }^{2}$ and RW Jayasekara ${ }^{2}$
}

(Index words: Abortion, ethical issues, genetic disorder)

\begin{abstract}
Introduction Prenatal diagnosis and pregnancy termination generate complex ethical issues. Surveys conducted in Sri Lanka among doctors and medical students in 1986 supported a change in law in favour of pregnancy termination when gross genetic defects are detected antenatally. A new generation of prenatal tests has focused attention again on the topic of termination and under what circumstances it might be legally done. The present survey contributes to the debate by means of a survey of doctors and medical students.
\end{abstract}

Method A self-administered questionnaire given to doctors and medical students.

Results Ninety three per cent of doctors and $81 \%$ of students accept pregnancy termination as an appropriate course of action if a gross genetic defect is detected antenatally, and $87 \%$ of doctors and $80 \%$ of students support a change in the law to allow termination of the pregnancy. The corresponding figures in previous surveys were $80 \%, 69 \%$ and $96 \%, 88 \%$ respectively.

Conclusions A majority of doctors and medical students support a change in law in favour of liberalising pregnancy termination when a genetic defect is detected antenatally.

\section{Introduction}

The debate surrounding the issues of termination of pregnancy, especially in the context of prenatal diagnosis, is fierce. [1-5]. Prenatal diagnosis is available in Sri Lanka and pregnant women are aware of these services. The laws of Sri Lanka forbid termination of non-viable pregnancies and force women to carry such pregnancies to term. The psychological trauma suffered by such women is evident to doctors caring for them [3]. Strong support for prenatal diagnosis and pregnancy termination in cases of foetal abnormality were reported in surveys conducted among doctors and medical students in 1986 [6-8]. As a part of a bigger survey we were conducting to study the attitudes of Sri Lankan doctors and medical students towards the new genetic and assisted reproductive technologies, we revisited the issue of prenatal diagnosis and pregnancy termination to see what, if anything, had changed regarding the views of doctors and medical students over time.

\section{Method}

The survey was conducted using a self-administered questionnaire. Some of the questions asked were intended to replicate those in surveys conducted in 1986. The venues for administering the questionnaires were the Faculty of Medicine and the Postgraduate Institute of Medicine of the University of Colombo, and the four teaching hospitals of the University of Colombo. The Ethical Review Committee of the Faculty of Medicine, University of Colombo approved the survey. Here we report the views expressed by respondents to questions on prenatal diagnosis and pregnancy termination.

\section{Results}

Two hundred and seventy eight doctors and 1256 medical students completed the questionnaire. The demographic characteristics of these two groups and the views expressed by them are summarised in Tables 1 and 2 .

In response to the three questions regarding the use of amniocentesis, doctors have become rather less positive over time (94-73\%). Likewise, in relation to its use where there are already genetic disorders or the mother is older than 35 years the proportions dropped from $98 \%$ to $87 \%$ and $78 \%$ to $71 \%$ respectively. There may be a futility factor at work here as evidenced by responses to open written comments: 'unnecessary expenditure as you can't change or do anything with your findings', 'no point doing amniocentesis when therapeutic abortion is not legalised'. Student responses have not changed significantly.

On multiple regression analysis in relation to these three questions, Protestants ( $\mathrm{p}=0.001$ ) were the most likely to feel that amniocentesis significantly affects the usefulness of genetic counselling with Hindus showing the least positive responses to the question. Unmarried people $(\mathrm{p}=0.045)$, the majority of whom were probably students, were more likely to advocate the use of amniocentesis in cases where Down syndrome already

${ }^{1}$ Department of Anthropology, University of Durham, UK; ${ }^{2}$ Human Genetics Unit, Faculty of Medicine, University of Colombo, Sri Lanka.

Correspondence: BS, Department of Anthropology, 43 Old Elvet, University of Durham, DH1 3HN, UK. Tel: 0191374 7659, Fax: 0191374 2870, e-mail: robert.simpson@durham.ac.uk (Competing interests: none declared). Received 5 March and revised version accepted 20 August 2003. 
exists in the family. The decision to offer amniocentesis to women over the age of 35 years was positively associated with students $(\mathrm{p}=0.002)$, all the religious groupings $(\mathrm{p}=0.013)$ with the exception of Moslems and women $(\mathrm{p}=0.023)$.

Table 1. Demographic characteristics of the doctors and medical students

\begin{tabular}{|c|c|c|c|c|}
\hline & \multicolumn{2}{|c|}{ Doctors } & \multicolumn{2}{|c|}{ Medical students } \\
\hline & Number & $\%$ & Number & $\%$ \\
\hline \multicolumn{5}{|l|}{ Age } \\
\hline $20-29$ & 44 & {$[17.4]$} & 1205 & [96] \\
\hline $30-39$ & 174 & {$[68.6]$} & & \\
\hline $40-49$ & 24 & {$[9.5]$} & & \\
\hline$>50$ & 2 & {$[0.8]$} & & \\
\hline Not stated & 9 & [3.6] & 51 & [4] \\
\hline \multicolumn{5}{|l|}{ Sex } \\
\hline Male & 166 & [66] & 682 & {$[54]$} \\
\hline Female & 77 & [30] & 524 & [42] \\
\hline Not stated & 10 & [4] & 49 & [4] \\
\hline \multicolumn{5}{|l|}{ Marital status } \\
\hline Single & 76 & [30] & 1205 & [96] \\
\hline Married & 168 & [66] & 12 & [1] \\
\hline Married, with children & 117 & [48] & 4 & {$[0.4]$} \\
\hline Not stated & 9 & [3.6] & 39 & [3] \\
\hline \multicolumn{5}{|l|}{ Religion } \\
\hline Buddhist & & & 1031 & [88] \\
\hline Hindu & & & 53 & {$[4.5]$} \\
\hline Roman Catholic & & & 5 & [63] \\
\hline Protestant/Anglican & & & 0.5 & {$[5]$} \\
\hline Moslem & & & 2 & [21] \\
\hline \multicolumn{5}{|l|}{$\begin{array}{l}\text { Awareness of Human } \\
\text { Genetics Unit }\end{array}$} \\
\hline Aware & 192 & [76] & 901 & [72] \\
\hline Not aware & 61 & [241] & 355 & [28] \\
\hline
\end{tabular}

Many respondents expressed concern at the idea of prenatal diagnosis to satisfy curiosity about sex as this might tempt some parents to seek pregnancy termination when female children were being carried. Unlike in neighbouring India, where the selective termination of female foetuses has contributed to a disruption of sex ratio and led to legislation to outlaw prenatal diagnosis for sex selection, the inclination towards gender selection in reproduction is relatively weak in Sri Lanka. Over the past 40 years, the sex ratio at birth in Sri Lanka has remained between 103 to 105 male births per 100 female births [9]. In multiple regression analysis students $(\mathrm{p}<0.001)$, men $(\mathrm{p}<0.001)$ and those without awareness of the Human Genetics Unit ( $\mathrm{p}=0.002)$ were most likely to feel that offering amniocentesis for finding out foetal sex was appropriate, suggesting that a combination of inexperience, gendered interest and lack of awareness may play a part in forming this view.

Among both doctors and students, the proportion in favour of pregnancy termination in circumstances where there was a gross genetic defect had increased over time. All the trainee family practitioners in the sample expressed support for this $(n=47)$. On multiple regression analysis, the respondents most likely to agree with the statement advocating termination, were Hindus and Buddhists $(\mathrm{p}=0.003)$, and those who were married $(\mathrm{p}<0.001)$.

On the question of pre-implantation genetic diagnosis (PGD) in relation to screening and possible termination about one third of both doctors and students were either against or undecided. The proportions in favour were $65 \%$ of doctors and $70 \%$ of students. However, if PGD did identify a genetic abnormality then discarding the embryos was acceptable to $84 \%$ of doctors and $80 \%$ of students. One possible interpretation of this discrepancy is that whereas there is some ambivalence over the PGD procedure in terms of safety and cost, there is rather less ambivalence when it comes to acting on the results. On multiple regression analysis, as in the previous question, Hindus and Buddhists $(\mathrm{p}=0.001)$ and married respondents $(\mathrm{p}=0.022)$ were the most likely to accept discarding of embryos. Different ideas about what constitutes the beginning of life in the main religious traditions may well play a part in explaining this result [10].

Eighty seven per cent of doctors and $80 \%$ of students were in favour of changing the law on abortion to allow termination in cases where there are genetic defects. These figures were lower than the proportions answering affirmatively in 1986 (96\% and 88\% respectively). Among both doctors and students there was a solid core of respondents drawn from each of the religious communities who were strongly opposed to allowing termination in these circumstances. There was, however, some variation. Protestants appeared to be the most opposed $(31 \%, n=4)$, followed by Moslems $(29 \%, n=7)$, Catholics $(19 \%, \mathrm{n}=19)$ and Buddhists $(14 \%, \mathrm{n}=178)$. The group least opposed were the Hindus with only $10 \%(n=9)$ opposed to such a change. The only significant variable 


\begin{tabular}{|c|c|c|}
\hline & $\%$ (number & e response \\
\hline & Doctors & Students \\
\hline Amniocentesis significantly affects the usefulness of genetic counselling & $\begin{array}{r}73 *(203) \\
94 * *\end{array}$ & 80 (1008) \\
\hline Amniocentesis is a good idea if a genetic disorder like & $87(242)$ & 87 (1093) \\
\hline Down syndrome has already appeared in the family. & 98 & 89 \\
\hline $\begin{array}{l}\text { Amniocentesis should be offered to all pregnant women } \\
\text { over the age of } 35 \text { years if there is legal provision for therapeutic abortion. }\end{array}$ & $\begin{array}{r}71(198) \\
78\end{array}$ & $\begin{array}{r}78(976) \\
72\end{array}$ \\
\hline $\begin{array}{l}\text { Amniocentesis should be offered to satisfy prenatal } \\
\text { curiosity about the sex of the foetus. }\end{array}$ & $\begin{array}{r}11(30) \\
30\end{array}$ & $\begin{array}{r}27(338) \\
32\end{array}$ \\
\hline $\begin{array}{l}\text { If by amniocentesis a gross genetic defect was detected } \\
\text { an abortion might be appropriate. }\end{array}$ & $\begin{array}{r}93(259) \\
89\end{array}$ & $\begin{array}{r}81(1013) \\
69\end{array}$ \\
\hline $\begin{array}{l}\text { Using pre-implantation genetic diagnosis (PGD) is an } \\
\text { acceptable way to screen for genetic disorders. }\end{array}$ & $\begin{array}{r}65(181) \\
\text { NA }\end{array}$ & $\begin{array}{r}70(878) \\
\text { NA }\end{array}$ \\
\hline $\begin{array}{l}\text { If yes, to previous question: If abnormalities are } \\
\text { identified through PGD it is acceptable to discard the embryos. }\end{array}$ & $84(232)$ & $\begin{array}{r}80(1000) \\
\text { NA }\end{array}$ \\
\hline $\begin{array}{l}\text { There should be provision made in the law to carry out } \\
\text { a therapeutic abortion when a genetic defect is detected antenatally. }\end{array}$ & $\begin{array}{r}87(239) \\
96\end{array}$ & $\begin{array}{r}80(1009) \\
88\end{array}$ \\
\hline
\end{tabular}

* figures in bold are the percentages reported for doctors and students in the present survey **figures in italics are the percentages reported for doctors and students in the 1986 survey NA-not available, these are new questions only included in the present survey.

identified in the regression analysis was marital status. Married respondents were more likely to favour a change in the law $(\mathrm{p}=0.010)$.

\section{Discussion}

Although the majority of doctors and students in this survey support some change in favour of liberalising pregnancy termination in certain circumstances, it is clear that a significant minority are fundamentally opposed to a change in the existing law. Correlation between support for pregnancy termination and variables such as age, whether a student or a doctor, number of children and marital status all point to the fact that those with greater personal and professional experience are likely to be more liberal on the question of prenatal testing and therapeutic termination. The strongest grounds for opposing pregnancy termination emerge from adherence to religious doctrine. All religions carry strong injunctions against the taking of life. In view of these beliefs, the fact that there is a majority in favour of change will do little to influence the minority who are implacably opposed as an article of faith.

Among those advocating a change in the law, the reasons given were various. Children with multiple disabilities are costly to care for and questions arise regarding effective distribution of scarce medical resources and services. Support services for the parents of severely disabled children are very limited in Sri Lanka. Having to tend a child with multiple needs can have a devastating impact on poor families. As one student puts it 'if a baby with incurable genetic disease is born, the baby and the parents are the ones that are going to suffer and not the law'. The absence of a legitimate route to safe pregnancy termination in circumstances where a serious genetic defect is identified may obviate some ethical dilemmas, but the responses of many in our survey suggest that its absence creates a whole lot more.

\section{Acknowledgements}

We thank the doctors and medical students who took part in the survey and Peter McCarthy of the University of Newcastle for statistical support. Bob Simpson holds a Wellcome Trust Fellowship under the Medicine in Society Programme (Biomedical Ethics GR067110AIA) for the year 2002-03.

\section{References}

1. Gunasekera PC, Wijesinghe PS. Reducing abortions is a public health issue. Ceylon Medical Journal 2001; 46: 41-4. 
2. Jayasuriya Lucian. Reducing abortions is a public health issue. Ceylon Medical Journal 2001; 46: 163.

3. Senanayake H M, de Silva MVC. Prenatal diagnosis of lethal congenital malformations in Sri Lanka. Ceylon Medical Journal 2001; 46: 163.

4. Wijesinghe P S, Gunasekera Prasanna. Reducing abortions is a public health issue. Ceylon Medical Journal 2002; 47: 74 .

5. Jayasuriya Lucian. Reducing abortions is a public health issue. Ceylon Medical Journal 2002; 47: 104.

6. Jayasekara R. Acceptance of a genetic service in Sri Lanka: a student viewpoint. Ceylon Journal of Medical Sciences 1986; 29: 67-73.
7. Jayasekara R, Kristl, GB, Wertelecki W. Acceptance of genetic service: a study of physicians in Colombo, Sri Lanka. Journal of Biosocial Sciences 1988; 20: 1-7.

8. Jayasekara R. The attitude of doctors and students towards a genetic service in an Asian country: Sri Lanka. Asia Oceania Journal of Obstetrics and Gynaecology 1989; 15: $267-270$.

9. Department of Census and Statistics. Statistical Abstract 2001. Department of Census and Statistics. Colombo. 2002.

10. Dissanayake VHW, Simpson R, Jayasekara RW. Attitudes towards the new genetic and assisted reproductive technologies in Sri Lanka: a preliminary report. New Genetics and Society 2002; 21: 65-74. 